\title{
Rancang Bangun Sistem Informasi Manajemen Barang Aset Dinas Perdagangan Kabupaten Jombang (SIMBADAG) Menggunakan Framework Codeigniter
}

\author{
Ali Masykur ${ }^{1}$, Endang Kurniawan ${ }^{2}$ \\ Universitas Pesantren Tinggi Darul Ulum Jombang ${ }^{1 \& 2}$ \\ masykurali4115071@gmail.com
}

\begin{abstract}
Abstrak - Menghadapi revolusi industry 4.0, Dinas Perdagangan Kabupaten Jombang memerlukan sistem manajemen aset berbasis online untuk mempermudah mengontrol aset lebih sistemik dan efisien. Oleh karena itu, perlu dibangun sebuah sistem informasi manajemen aset Dinas Perdagangan Jombang (SIMBADAG) untuk mengatasi permaslahan tersebut. SIMBADAG dibangun menggunakan teknologi web memakai bahasa pemrograman PHP (Personal Home Page) dan HTML (Hypertext Markup Language) serta menggunakan database MySQL, sehingga dapat memusatkan data informasi aset Dinas Perdagangan Jombang. SIMBADAG dilengkapi dengan fitur login sebagai keamanyannya dan tampilan menu atau penggunaan fitur yang mudah dipahami (user friendly). Pengumpulan data dilakukan melalui wawancara pegawai dinas, studi pustaka untuk mencari referensi terkait penelitian rancang bangun SIMBADAG dan observasi lapangan pada Dinas Perdagangan Kabupaten Jombang. hasil uji coba,diketahui bahwa SIMBADAG dapat memudahkan dalam penyusunan, pengelolaan, penyimpanan serta pencarian data aset dan laporan Dinas Perdagangan Jombang.
\end{abstract}

Kata kunci: rancang bangun, aset, simbadag, framework codeigniter.

\section{Latar Belakang}

IImu komputer yang terus dikembangkan mempermudah penerapan teknologi informasi untuk membantu memfasilitasi dalam segala bidang, terutama dalam bidang pemerintahan. Dilihat dari banyaknya data yang perlu diolah untuk dijadikan informasi, maka penerapan teknologi informasi dalam bidang pemerintahan mempunyai peran penting. Salah satu instansi pemerintahan yang membutuhkan peran teknologi informasi adalah Dinas Perdagangan Kabupaten Jombang.

Dinas Perdagangan Kabupaten Jombang merupakan satuan kerja perangkat pemerintahan daerah yang memiliki tugas pokok untuk melaksanakan sebagian urusan di bidang perdagangan. Dinas Perdagangan Kabupaten Jombang terletak di JL. KH. Wahid Hasyim No. 143 Jombang melakukan sebagian tugas dalam merencanakan, melaksanakan, mengkoordinasikan, dan mengendalikan kegiatan administrasi umum, keuangan dan aset, penyusunan program, dan pelaporan. Seperti umumnya instansi pemerintahan, Dinas Perdagangan Kabupaten Jombang mempunyai banyak data yang perlu diolah untuk dijadikan informasi yang dibutuhkan, terutama mengenai data laporan dinas dan data aset dinas seperti data aset kendaraan, data aset tanah gedung dan bangunan, serta data aset barang dan peralatan. Namun untuk saat ini, pengelolaan atau penyusunan informasi barang aset dinas dan laporan dinas masih menggunakan cara yang kurang efektif, yaitu dengan cara melakukan penyusunan data menggunakan Ms. Word kemudian dicetak menjadi hard file dan disimpan dalam buku besar, sehingga membutuhkan waktu yang cukup lama dalam proses pengelolaanya maupun pencarianya. Karena banyaknya data atau informasi barang aset dinas, maka ketika sewaktu-waktu diperlukanya sebuah data atau informasi barang aset dinas, yang terjadi adalah dibutuhkanya waktu lebih untuk pencarianya. Begitupun dalam pengelolaan laporan dinas seperti laporan KIR (Kartu Inventaris Ruangan), laporan BAP (Berita Acara Penanggungjawab), dan laporan rutin dinas, pengelolaanya masih menggunakan cara yang kurang efektif, seperti pengelolaan aset dinas.

Maka dari itu diperlukan sebuah sistem yang dapat memudahkan dalam penyusunan, pengelolaan, penyimpanan serta pencarian data aset dan laporan Dinas Perdagangan Jombang dianggap penting. Oleh karena itu diusulkan perancangan dan pembangunan Sistem Informasi Barang Aset Dinas Perdagangan Kabupaten

Rancang Bangun Sistem Informasi Manajemen Barang Aset Dinas Perdagangan Kabupaten Jombang (SIMBADAG) Menggunakan Framework Codeigniter 
Jombang (SIMBADAG) Menggunakan Framework Codeigniter.

\section{a. Rumusan Masalah}

Adapun rumusan masalah pada penelitian ini adalah :

1) Bagaimana cara merancang dan membangun sistem informasi manajemen aset Dinas Perdagangan Kabupaten Jombang?.

2) Bagaimana cara memanfaatkan framework codeigniter dalam perancangan dan pembangunan sistem informasi manajemen aset Dinas Perdagangan Kabupaten Jombang?.

3) Apakah sistem informasi manajemen barang aset Dinas Perdagangan Jombang dapat membantu penyusunan, pengelolaan, penyimpanan serta pencarian data aset dan laporan Dinas Perdagangan Jombang?.

\section{b. Batasan Masalah}

Adapun batasan masalah pada penelitian ini adalah :

1) Data yang menjadi acuan adalah data aset dinas meliputi data aset kendaraan, data aset tanah gedung dan bangunan, serta data aset barang dan peralatan serta laporan yang menjadi acuan adalah laporan KIR (Kartu Inventaris Ruangan), laporan BAP (Berita Acara Penanggungjawab), dan laporan rutin dinas.

2) Fitur-fitur yang digunakan adalah fitur pengeloalaan data aset, dan laporan, serta monitoring data aset dan laporan.

3) Teknologi yang digunakan dalam perancangan adalah teknologi PHP dan HTML, menggunakan database MySQL serta menggunakan framework Codeigniter

4) Karena kurangnya SDM serta demi terjaganya data aset dinas, maka aktor dari sistem informasi manajemen aset Dinas Perdagangan Kabupaten Jombang ini hanyalah admin.

\section{Kajian Pustaka}

\section{a. Penelitian Terdahulu}

Terdapat beberapa penelitian terdahulu yang digunakan sebagai rujukan dalam menyelesaikan masalah pencarian secara konvensional diantaranya :

Rujukan pertama yaitu Aprillisa Ragita dan Wirawan (2013) yang menghasilkan sebuah sistem yang memberikan informasi lengkap dan pelayanan personal kepada donatur,serta memberika kemudahan kegiatan operasional bagi user.

Rujukan kedua yaitu Hartanto dan Zairen (2013) yang menghasilkan sebuah sistem SIMPEG berbasis web dengan bahasa pemrograman HTML (Hypertext Markup Language) dan PHP (Personal Home Page) yang berguna untuk memudahkan Badan Kepegawaian Daerah (BKD) Kabupaten Maluku Tenggara dalam melakukan pelayanan kepegawaian yang berhubungan dengan administrasi kepegawaian.

Rujukan ketiga Pambudi, Sriyanto, dan Arvianto(2017) yang menghasilkan sebuah Sistem Informasi Manajemen Aset (SIMA) berbasis web di Teknik Industri UNDIP yang dapat memudahkan pendataan barang inventaris dan barang habis serta kemudahan pengawasan langsung dari ketua jurusan.

Rujukan keempat Putra (2018) yang menghasilkan Sistem Informasi Manajemen Aset Di Fakultas Sains Dan Informatika Universitas Jendral Achmad Yani yang digunakan untuk membantu pencatatan dan pemeliharaan aset, serta membantu menampilkan informasi sebagai bahan pengambilan keputusan.

Rujukan kelima Senjaya, Witanti dan Umbara (2018) yang menghasilkan sistem informasi manajemen aset di Rumah Sakit Jiwa Provinsi Jawa Barat yang digunakan untuk memantau pendistribusian aset, pendokumentasian aset, monitoring aset, serta dapat memberikanstatus aset secara real time.

\section{b. Sistem Informasi Manajemen (SIM)}

Sistem Informasi Manajemen (SIM) merupakan jaringan informasi yang dibutuhkan pimpinan dalam menjalankan tugasnya (untuk kepentingan organisasi), terutama dalam mengambil keputusan dalam mencapai tujuan organisasinya. Teknik SIM untuk memberi manajer informasi yang memungkinkan mereka merencanakan serta mengendalikan operasi. Komputer telah menambah satu atau dua dimensi, seperti kecepatan, ketelitian dan volume data yang meningkat, yang memungkinkan pertimbangan alternatif-alternatif yeng lebih banyak dalam suatu keputusan, yang di dalam suatu organisasi terdiri atas sejumlah unsur, orang yang mempunyai bermacam-macam peran dalam organisasi, kegiatan atau tugas yang harus diselesaikan,

Rancang Bangun Sistem Informasi Manajemen Barang Aset Dinas Perdagangan Kabupaten Jombang

(SIMBADAG) Menggunakan Framework Codeigniter 
tempat bekerja, wewenang pekerjaan, serta hubungan komunikasi yang mengikat bersama organisasi tersebut. SIM merupakan penerapan sistem informasi di dalam organisasi untuk mendukung informasi-informasi yang dibutuhkan oleh semua tingkatan manajemen. Tekanan SIM itu pada sistemnya, bukan pada manajemennya, tetapi agar SIM itu dapat berlangsung dengan efektif dan efisien, perlu dikelola sebaik-baiknya. Sistem informasi dalam pentahapannya dapat digambarkan sebagai struktur piramida, dengan lapisan paling bawah meliputi informasi bagi proses transaksi, pemeriksaan mengenai status, dan lain sebagainya. Tahap berikutnya meliputi sumber informasi untuk mendukung perencanaan taktis dan pengambilan keputusan bagi pengawasan dan tahap puncak meliputi sumber informasi guna menunjang perencanaan dan pengambilan kebijakan oleh manajemen yang lebih tinggi (Lipursari 2013).

\section{c. Aset}

Aset adalah barang/benda yang dapat dimiliki dan mempunyai nilai ekonomis (economic value), nilai komersial atau nilai pertukaran yang dimiliki atau digunakan suatu badan usaha, lembaga atau perorangan. Aset adalah barang tidak bergerak dan barang bergerak yang dibeli atas beban Anggaran Pendapatan dan Belanja Negara dan perolehan lain yang sah, yang dimiliki/dikuasai oleh kementerian/lembaga, badan-badan, tidak termasuk kekayaan yang dipisahkan dan bukan kekayaan pemerintah daerah. Untuk itu, pemerintah harus benar- benar memahami apa saja yang harus dilakukan sehingga dapat mengoptimalkan aset-aset yang dimiliki guna meningkatkan pendapatan pemerintah khususnya dalam hal ini adalah aset tetap tanah dan bangunan (Octanary 2018).

\section{d. Framework Codeigniter}

framework Codelgniter merupakan framework PHP yang dibuat berdasarkan model view Controlleer (MVC). Framework codeigniter yaitu memiliki library yang lengkap untuk mengerjakan operasi-operasi yang umumnya dibutuhkan oleh aplikasi berbasis web misalnya mengakses database, memvalidasi form sehingga sistem yang dikembangkan mudah. framework codeigniter juga menjadi satu-satunya framework dengan dokumentasi yang lengkap dan jelas. Source code framework codeigniter yang dilengkapi dengan comment didalamnya sehingga lebih memperjelas fungsi sebuah kode program dan framework codeigniter yang dihasilkan sangat Bersih (clean) dan search Engine Friendly (SEF).

Codeigniter juga dapat memudahkan developer dalam membuat sistem berbasis web berbasis PHP, karena framework sudah memiliki kerangka kerja sehingga tidak perlu menulis semua kode program dari awal. Selain itu, struktur dan susunan logis dari codeigniter membuat sistem menjadi semakin teratur dan dapat fokus pada fitur-fitur apa yang akan dibutuhkan dalam pembuatan aplikasi tersebut (Destiningrum and Adrian 2017).

\section{Perancangan Sistem / Metode Penelitian}

\section{a. Pengumpulan Data}

Pengumpulan data dilakukan melalui wawancara pegawai dinas, studi pustaka untuk mencari referensi terkait penelitian rancang bangun SIMBADAG dan observasi lapangan pada Dinas Perdagangan Kabupaten Jombang.

\section{b. Analisis Sistem Berjalan}

Seperti umumnya instansi pemerintahan, Dinas Perdagangan Kabupaten Jombang mempunyai banyak data yang perlu diolah untuk dijadikan informasi yang dibutuhkan, terutama mengenai data laporan dinas meliputi laporan KIR (Kartu Inventaris Ruangan), laporan BAP (Berita Acara Penanggungjawab), dan laporan rutin dinas,serta data aset dinas seperti data aset kendaraan, data aset tanah gedung dan bangunan, serta data aset barang dan peralatan. Namun untuk saat ini, pengelolaan atau penyusunan informasi barang aset dinas dan laporan dinas masih menggunakan cara yang kurang efektif, yaitu dengan cara melakukan penyusunan data menggunakan Ms. Word kemudian dicetak menjadi hard file dan disimpan dalam buku besar, sehingga membutuhkan waktu yang cukup lama dalam proses pengelolaanya maupun pencarianya.

Berdasarkan analisis sistem pengelolaan aset dan laporan yang sedang berjalan pada Dinas perdagangan Jombang ada beberapa masalah yang terjadi, yaitu:

1) Karena banyaknya data aset dan laporan yang dimiliki dinas, maka pencarian akan membutuhkan waktu yang cukup lama.

2) Karena pengelolaan mulai dari pembuatan sampai cetak masih melakukan data secara manual, maka proses pengelolaan akan memakan banyak waktu dan besar kemungkinan terjadinya kesalahan. 
3) Karena banyaknya barang aset dinas, maka sulit langsung diketahui ketika ada salah satu aset kendaraan membutuhkan pajak rutin.

\section{c. Analisis Sistem yang Diusulkan}

Berdasarkan hasil analisis pada sistem yang berjalan saat ini. Untuk mengatasi permasalahan yang telah disebutkan, maka dalam penelitian ini diusulkan sebuah Sistem Informasi Manajemen Aset Dinas Perdagangan (SIMBADAG) Jombang berbasis web. Penelitian ini diharapkan dapat memberikan solusi masalah dengan membuat sistem yang dapat membantu pengelolaan aset secara optimal melalui cara online dan dapat memonitoring data aset secara optimal. Akan ditampilkan pada Gambar 1.

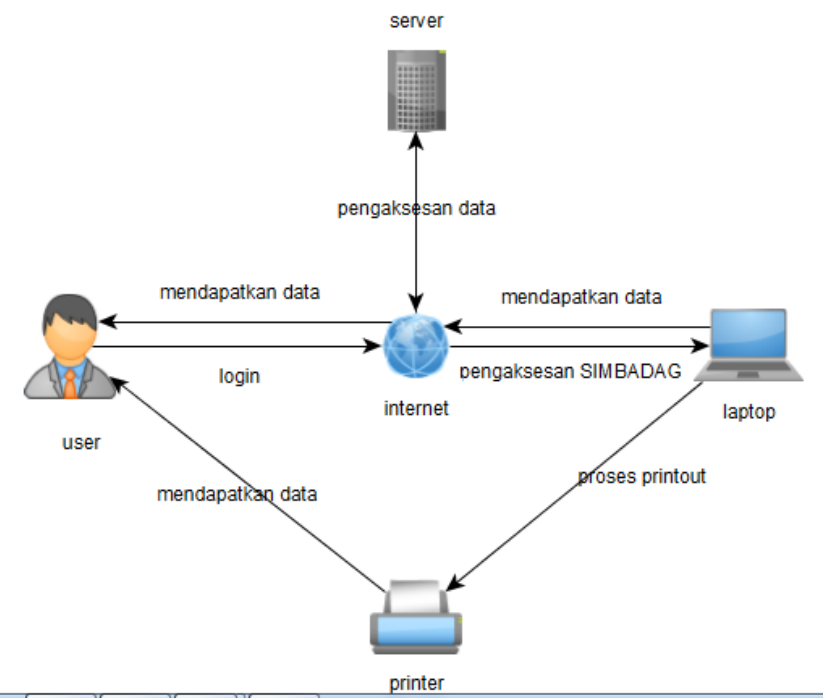

Gambar 1. Alur SIMBADAG

\section{d. Analisis Kebutuhan}

1) Kebutuhan Fungsional

Kebutuhan fungsional yang yang dimiliki oleh sistem informasi manajemen barang aset Dinas Perdagangan Jombang adalah:

a) Adanya fasilitas untuk membuat laporan dinas meliputi laporan KIR (Kartu Inventaris Ruangan), laporan BAP (Berita Acara Penanggungjawab), dan laporan rutin dinas,serta data aset dinas seperti data aset kendaraan, data aset tanah gedung dan bangunan, serta data aset barang dan peralatan.

b) Adanya fasilitas CRUD (Create Read Update Delete) pada setiap laporan.

c) Adanya fasilitas pengumpulan dan penyimpanan laporan.
e-ISSN : 2656-615X

d) Adanya fasilitas monitoring data aset kendaraan, untuk memonitoring pajak kendaraan setiap waktu.

Adanya fasilitas searching unntuk memudahkan proses pencarian data

\section{2) Kebutuhan Non Fungsional}

Kebutuhan non fungsional yang yang dimiliki oleh sistem informasi manajemen barang aset Dinas Perdagangan Jombang adalah:

a) Sistem mempunyai tampilan user friendly yang memudahkan pengguna untuk mengoperasikanya.

b) Menggunakan sistem login unntuk kemamanan data.

c) Menggunakan teknologi website untuk memudahkan pengaksesanya.

d) Spesifikasi minimum
[1] Sistem Operasi Microsoft Windows 7.1
[2] Processor Intel(R) Core(TM)2 Duo CPU T5870
[3] RAM 2GB
[4] HDD $320 \mathrm{~GB}$
[5] VGA $1 \mathrm{~GB}$
[6] Web Browser.

\section{e. Perancangan}

Pada tahapan ini dilakukan proses perancangan sistem, baik itu rancangan tampilan visual (interface) sistem maupun rancangan program. Aplikasi marketplace lembaga kursus dan pelatihan Bahasa Inggris digunakan dengan menggunakan Unified Modeling Language (UML) yang meliputi Use case Diagram, Activity Diagram, Sequence Diagram. Software yang digunakan dalam perancangan yaitu aplikasi StarUML. Sedangkan desain user interface menggunakan aplikasi Balsamic

\section{1) Usecase Diagram}

Pemodelan Use case sistem informasi manajemen barang aset di Dinas Perdagangan Kabupaten Jombang, digunakan untuk mendeskripsikan aktor dan aktivitas yang dilakukan oleh aktor. Karena keterbatasan sumber daya di Dinas Perdagangan Kabupaten Jombang, maka pihak dinas mengusulkan agar actor dari sistem ini hanyalah satu yaitu user. Untuk tugas dan fungsi user dalam sistem, dapat dilihat pada Gambar 2. 
SISTEM INFORUASI IANANEIMEN ASET BARANG DNAS PERDAGANGAN (SIMBADAG) JOMBANG

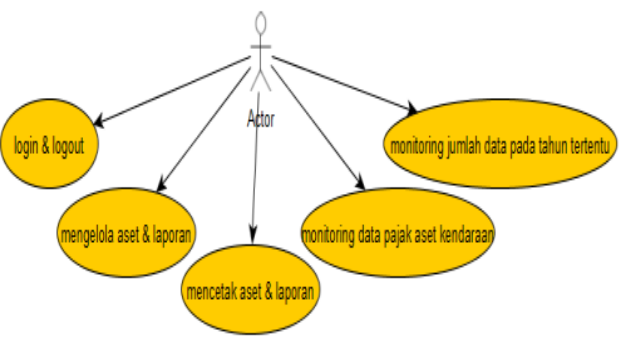

Gambar 2. Usecase Diagram

\section{2) Class Diagram}

Class diagram dibuat sesuai dengan sequence. Pada dasarnya hanya ada satu class diagram. Akan tetapi, apabila terlalu besar class diagram dapat dipecah pecah sesuai kebutuhan asal tidak mengubah maksud dari relasi antar class. Secara rinci class diagram dapat dilihat pada gambar 3 .

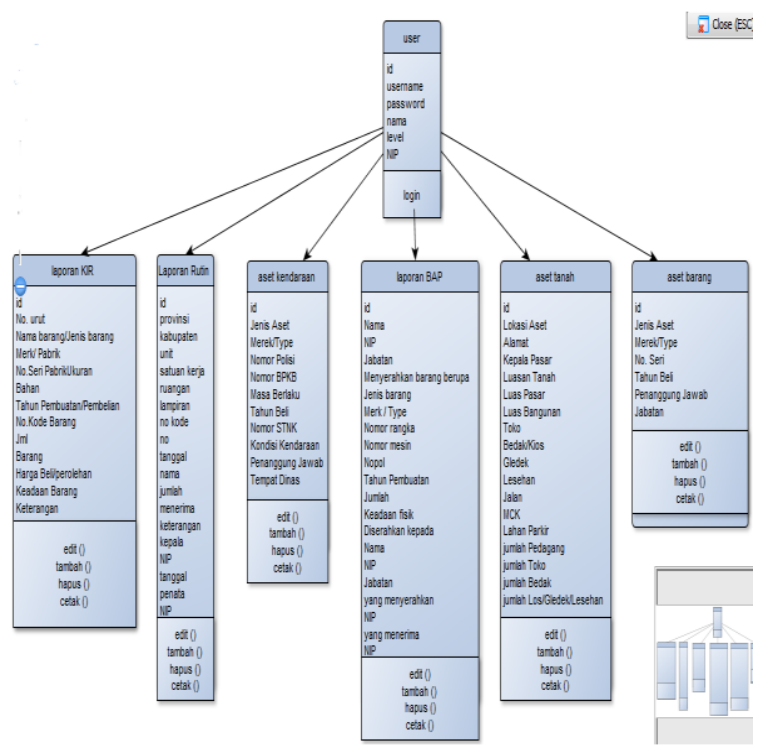

Gambar 3. Class Diagram

\section{Implementasi Sistem dan Hasil}

Implementasi Sistem dan Hasil rancang bangun SIMBADAG berbasis web secara detail sebagai berikut.

\section{a. Halaman Login}

Pada halaman ini dapat melakukan login dengan cara mengisi form username dan password. Jika data yang diisikan sesuai maka akan masuk halaman beranda, Dapat dilihat pada Gambar 4.

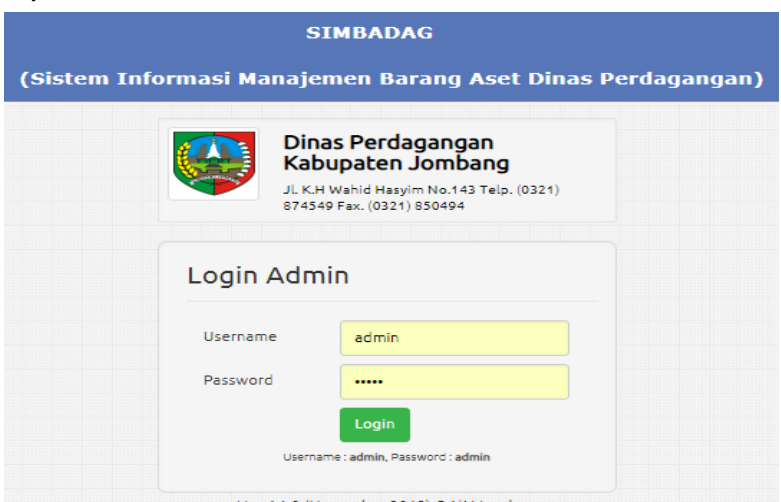

Gambar 4. Halaman Login

\section{b. Halaman Beranda}

Pada halaman beranda akan menampilkan monitoring jumlah data aset dan data laporang yang telah masuk ke database SIMBADAG. Tampilan beranda dapat dilihat pada Gambar 5.

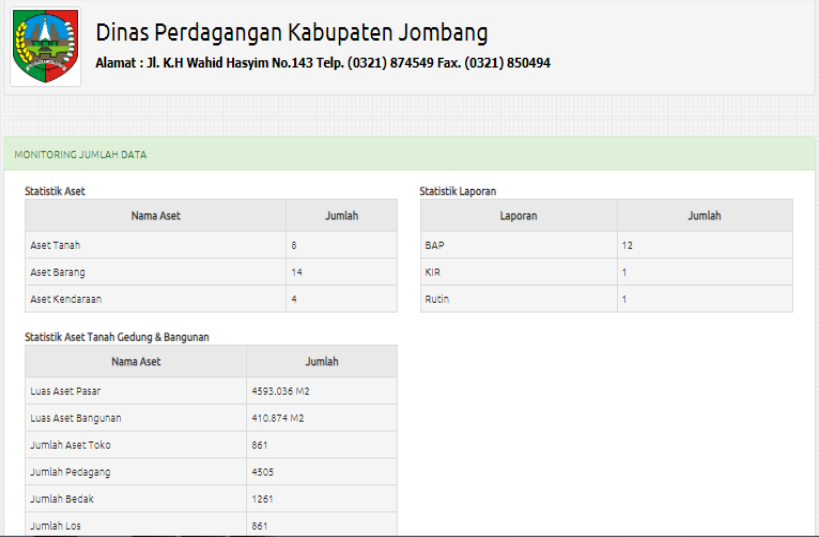

Gambar 5. Halaman Beranda

\section{c. Halaman Aset dan Laporan}

Halaman utama digunakan untuk menampilkan data aset sesuai fitur aset atau laporan yang dipilih, dapat dilihat pada Gambar 6.

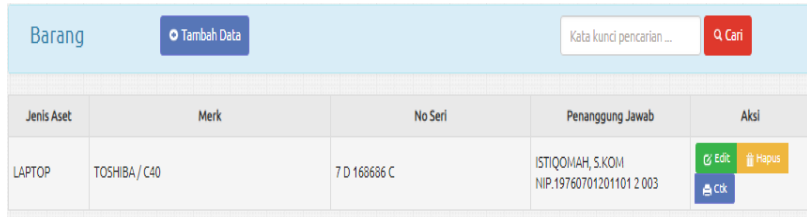

Gambar 6. Halaman Aset Barang

\section{d. Halaman Form}

Rancang Bangun Sistem Informasi Manajemen Barang Aset Dinas Perdagangan Kabupaten Jombang (SIMBADAG) Menggunakan Framework Codeigniter 
Halaman form tampil ketika tambah data atau edit data, Dapat dilihat pada Gambar 7.

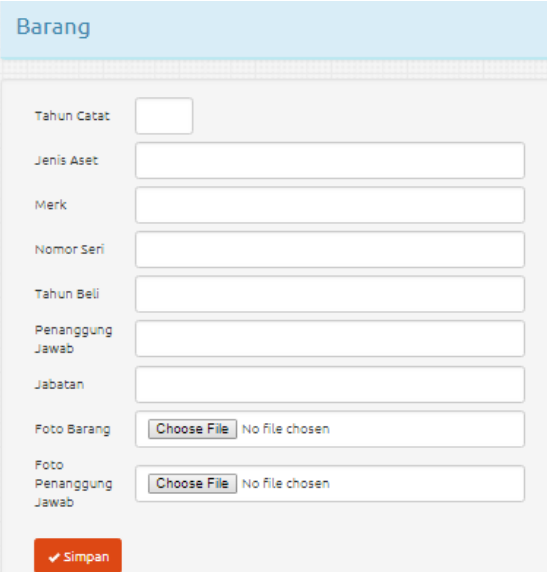

Gambar 7. Halaman Form Tambah Data Aset Barang

\section{e. Halaman Cetak}

Halaman cetak tampil ketika memilih button cetak pada data aset atau laporan, Dapat dilihat pada Gambar 8 .

\begin{tabular}{|c|c|}
\hline D & 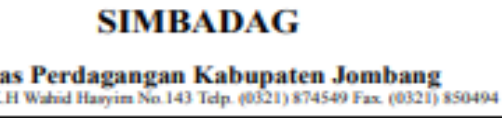 \\
\hline & Data Base Kendaraan \\
\hline Jenis Aset & $\sec 2$ \\
\hline Mterk/Type & :HONDA / MCB \\
\hline Nemar Palai & S 2819 WP \\
\hline Nemar BPKE & $C-3426222 \mathrm{~J}$ \\
\hline Mtana Berlaku & $2022-10-19$ \\
\hline Tahue Beli & 2000 \\
\hline Nemar SINXK & :HABBE - 1043048 \\
\hline Keadihi Kendaran & : BAIK \\
\hline Penanezune Jawab & SAD MGUS RLIDI UTOMAO NIP. 19600814200501 I 003 \\
\hline Ienepat Dins & KANTOER DENAS \\
\hline Fela STIK & \\
\hline Foba Keadaraan & \\
\hline $\begin{array}{l}\text { Fon Praxagerage } \\
\text { Jowab }\end{array}$ & \\
\hline
\end{tabular}

Gambar 8. Tampilan Cetak Aset Kendaraan

\section{f. Halaman Ganti Password}

Halaman form tampil ketika memilih fitur rubah Password7. Dapat dilihat pada gambar 9.

Rancang Bangun Sistem Informasi Manajemen Barang Aset Dinas Perdagangan Kabupaten Jombang

(SIMBADAG) Menggunakan Framework Codeigniter
Ubah Password

Username

admin

Password lama

Password baru

Ulangi Password baru

\section{$\leftarrow$ Simpan Kembali}

Gambar 9. Halaman Ganti Password

\section{Kesimpulan}

Berdasarkan uji coba dan implementasi aplikasi yang telah dilakukan, maka dapat diambil kesimpulan sebagai berikut:

1) Sistem Informasi Manajemen Barang Aset Dinas Perdagangan berbasis web dapat membantu mempermudah mengatasi permasalahan pengelolaan data aset dan laporan dinas mulai dari penyusunan, penyimpanan, sampai percetakan.

Sistem Informasi Manajemen Barang Aset Dinas Perdagangan berbasis web dapat membantu mempermudah pegawai dinas dalam mengelola serta memonitoring data aset dan laporan dinas.

Dengan menggunakan Sistem Informasi Manajemen Barang Aset Dinas Perdagangan berbasis web maka dapat dengan mudah mengetahui aset kendaraan yang telah jatuh tempo waktu membayar pajak.

\section{Pustaka}

[1] Aprillisa, R., \& Wirawan, A. R. (2013). Analisis Dan Perancangan Sistem Informasi Manajemen Hubungan Terhadap Donatur Untuk Meningkatkan Loyalitas Dan Jumlah Donatur Vihara Dhammadipa Surabaya: 14.

[2] Destiningrum, M., \& Adrian, Q.J. (2017). Sistem Informasi Penjadwalan Dokter Berbassis Web Dengan Menggunakan Framework Codeigniter (Studi Kasus: Rumah Sakit Yukum Medical Centre), Jurnal TEKNOINFO, 11(2), pp 8. 
Retrieved Desember 21, 2018 from http://ejurnal.teknokrat.ac.id/index.php/te knoinfo/article/downloadSuppFile/24/1

[3] Lipursari, A. (2013). Peran Sistem Informasi Manajemen (SIM) Dalam Pengambilan Keputusan, Jurnal STIE Semarang, 5(1), pp 12. Retrieved Desember 21, 2018 from

https://media.neliti.com/media/publicatio ns/132855-ID-peran-sistem-informasimanajemen-sim-dal.pdf

[4] Octanary, D. (2018). Analisis Manajemen Aset Pada Satuan Kerja Pemerintah Pusat Di Kota Palu, pp 11.

[5] Pambudi, G. S., Sriyant, S., \& Arvianto, A. (2017). Rancang Bangun Sistem Informasi Manajemen Aset Berbasis Web Untuk Optimalisasi Penelusuran Aset Di Teknik Industri Undip. Jurnal Teknik Industri, 11(3).

[6] Putra, I. P. (2018). Pembangunan Sistem Informasi Manajemen Aset Di Fakultas Sains Dan Informatika Universitas Jenderal Achmad Yani, Prosiding SNST 9. Retrieved Desember 21, 2018 from https://publikasiilmiah.unwahas.ac.id/inde x.php/PROSIDING_SNST_FT/article/dow nload/2393/2379.

[7] Senjaya, M. T., Witanti, W., \& Umbara, F.R. (2018). Pembangunan Sistem Informasi Manajeman Aset Di Rumah Sakit Jiwa Provinsi Jawa Barat, Prosiding SENIATI 4. Retrieved Desember 22, 2018 from https://ojs.amikom.ac.id/index.php/semna steknomedia/article/download/2038/1847.

[8] Zairen, D., \& Hartanto, A.D. (2013). Analisis

Dan Perancangan Sistem Informasi Manajemen Kepegawaian (Simpeg) Pada Badan Kepegawaian Daerah Kabupaten Maluku Tenggara 14(04),

Retrieved Desember 22, 2018 from https://ojs.amikom.ac.id/index.php/dasi/art icle/view/200. 